DOI: $10.1515 /$ pts-2016-0041

\title{
PERFORMANCE EVALUATION OF PHOTOVOLTAIC SOLAR AIR CONDITIONING
}

\author{
A.Snegirjovs ${ }^{1}$, P.Shipkovs ${ }^{1}$, K. Lebedeva ${ }^{1}$, \\ G. Kashkarova ${ }^{1}$, L.Migla ${ }^{1}$, \\ P. Gantenbein ${ }^{2}$, L. Omlin² \\ ${ }^{1}$ Institute of Physical Energetics, \\ 11 Krivu Street, Riga, LV-1006, LATVIA \\ ${ }^{2}$ Institut für Solartechnik SPF, \\ Oberseestrasse 10, CH-8640 Rapperswil, SWITZERLAND
}

Information on the electrical-driven solar air conditioning (SAC) is rather scanty. A considerable body of technical data mostly concerns largescale photo-voltaic solar air conditioning (PV-SAC) systems. Reliable information about the energy output has arisen only in recent years; however, it is still not easily accessible, and sometimes its sources are closed. Despite these facts, solar energy researchers, observers and designers devote special attention to this type of SAC systems. In this study, performance evaluation is performed for the PV-SAC technology, in which low-power (up to $15 \mathrm{~kW}$ of cooling power on average) systems are used. Such a system contains a PV electric-driven compression chiller with cold and heat sensible thermal storage capacities, and a rejected energy unit used for preheating domestic hot water (DHW). In a non-cooling season, it is possible to partly employ the system in the reverse mode for DHW production. In this mode, the ambient air serves as a heat source. Besides, free cooling is integrated in the PV-SAC concept.

Keywords: solar energy, electrical-driven, solar air conditioning, performance evaluation.

\section{INTRODUCTION}

Expected increase in the cooling loads for comfort needs in private and office buildings calls for alternatives to the conventional energy sources in order to reduce global greenhouse gas emissions, e.g., CO2. Reduction in the component costs and innovative solutions in the area of solar energy technologies open wider opportunities for their application in different building sectors. The solar cooling communities from SHC IEA report about the increase in the number of solar cooling and air conditioning systems in the last decade. These authors offer several ways for conversion of the solar radiation into cold using solar cooling components. Today, the most popular technologies are thermal-driven ab- and adsorption chillers in combination 
with solar thermal collectors. However, due to high costs of the sorption machines and collectors, the market for these technologies is growing very slowly. At the same time, the photo-voltaic (PV) market develops fast, with continuously reduced PV module prices. This economical reason increases the attractiveness of solar-electrical air conditioning systems. Therefore, the coupling of PV modules with an electrical-driven system of the type presents the concept of PV-based air conditioning. It should be noted that all components of PV electricity driven air conditioning systems are commercially available.

Electric-driven heating and cooling equipment, such as vapour compression heat pumps (HPs), chillers or reversible HPs, in connection with hot and/or cold storages is an attractive option for the energy supply in buildings. However, except for some European regions, today only a few complete system solutions using photovoltaics for the energy supply in buildings are available on the market. Therefore, a lack of information on the overall cost and performance of such systems is identified.

\section{PERFORMANCE EVALUATION}

The experimental results [1] confirm the operability of PV-SAC technology. Additionally, the parameters of operation under critical conditions have been obtained. The experiments have shown appropriate functionality of the system at temperature and power fluctuations. Even in critical situations no failures of the system's inside and outside components took place. Stable and predictable operation of the system was also observed in the autonomous regime.

The simulation results show that the full cooling demand can be covered using PV-SAC technology in a standard single-family house. It has been found that PV power is sufficient for the maximum electricity consumption of the system. The results show that for effective use of PV-generated power the electricity accumulation is needed.

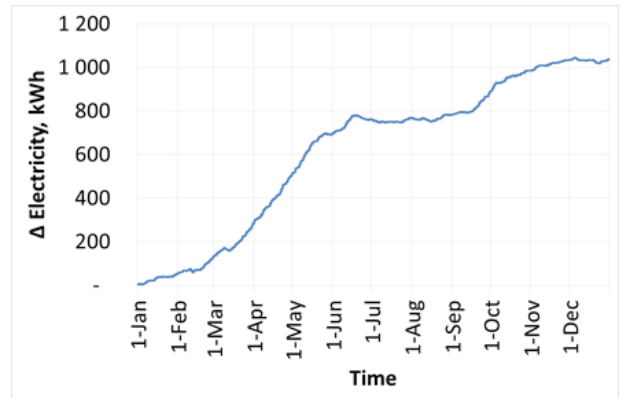

a)

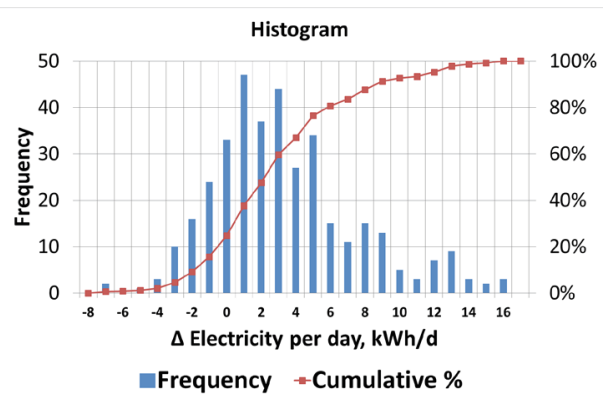

b)

Fig. 1. Imbalance of electricity generation $(+)$ and electricity consumption (-) of the system

( $\Delta$ Electricity): a) cumulative annual result, b) daily results of one-year operation.

Figure 1a shows imbalance between the electricity generation by the PV array and the electricity consumption by the cold production and distribution component 
of the system. It is seen that such imbalance is more stable in a cooling season in compliance with the design of PV and SAC components. For DHW preheating in a non-cooling season, the reverse mode is used. Higher electricity overproduction is observed in the inter-seasonal periods, which is due to combination of high PV electricity generation and freezing protection. Enhancement of defrosting the outdoor air-water heat exchanger leads to a significant decrease in the electricity overproduction. The daily electricity imbalance seen in Fig. $1 \mathrm{~b}$ is from $-3 \mathrm{kWh} /$ day to +9 $\mathrm{kWh} /$ day in $90 \%$ of the days. The installation of an electrical accumulator with the capacity of at least $6 \mathrm{kWh}$ covers periodical electricity overconsumption in a cooling season. Decreasing the accumulator capacity exponentially increases the cooling deficit up to $41 \%$.

Electricity unavailability might lead to immediate shutdown of the system. Such being the case, first of all the heat from the hot side of cooling machine should be rejected, while its cold side should be protected from freezing. For this purpose, two circulation pumps continue operation after the compressor stops. Second, the prepared cold should be distributed, for which electricity is also consumed. Respectively, PV-SAC operation without electricity accumulators will extremely reduce the lifetime of the system as well as its efficiency. Moreover, this may cause unrecoverable destruction of the system components.

The thermal energy storages allow smoothing the peaks of cold production and heat rejection, thus reducing the load of cooling machine and improving its performance. The heat production and redirection are also possible owing to hot storage implementation. Our results show that $26 \%$ of rejected heat is redirected to the DHW heating, with the heat needs for DHW fully satisfied by PV-SAC in a cooling season.

High cold preparation performance is achieved by free cooling. Unfortunately, free-cooling regime could be limited by weather conditions.

\section{FINANCIAL PROFITABILITY ASSESSMENT}

In the financial profitability assessment, the results for PV-SAC yield are used. In the reference building and under reference conditions, the PV-SAC technology meets a cold demand of $5 \mathrm{MWh} / \mathrm{a}$ and a heat demand of $2.6 \mathrm{MWh} / \mathrm{a}$. Additionally, 1 $\mathrm{MWh} / \mathrm{a}$ of electricity is generated.

The initial investment in PV-SAC is with $5 \mathrm{~kW}$ cooling power 1700 Euro. Additional costs of the high precision measuring equipment are excluded as not required in conventional PV-SAC applications.

Thermal insulation is included. Thermal storages are pre-insulated. The cooling machine contains two circulation pumps. The CM-integrated control unit is able to control the operation of compressor, the cold side and the cold side circulation pumps, and the outdoor unit. To control the operation of cold distribution pump, mixing valve, three-way valves as well as the free-cooling mode, an additional control unit is required.

The installation costs are highly variable due to several reasons. First, these costs depend on the particular location and building type. Second, they depend on 
the salary level in the engineering sectors in the particular region. Third, the costs of equipment to be installed are determined by its class. Future widespread applications of PV-SAC technologies would improve the workmanship, thus reducing the installation costs. In the financial profitability assessment, the estimated average costs of PV-SAC installation in European regions are applied.

Maintenance costs include periodical system's check and adjustment. Brine should be replaced every 7 years of system operation. The lifetime of the main system part is 20 years. Three circulation pumps have a shorter lifetime: they should be replaced after 10 years. Respectively, the average maintenance costs are 87 Euro per year.

The financial profitability of PV-SAC is assessed in comparison with the conventional air conditioning and heating $(\mathrm{CAC} \& \mathrm{H})$. The cost of a split-type CAC system with the COP rate of 3.0 is 1200 Euro including installation, and its average lifetime is 5 years.

The average price of electricity for household consumers in the EUmix (the prices for 28 European Union member states are weighed according to their consumption by the household sector) was 0.208 Euro per $\mathrm{kWh}$ in the second half of 2014 [2]. The price of heat energy includes the natural gas price and takes into account the efficiency of boiler. In the second half of 2014, the price of natural gas for a medium-sized household within the EUmix was 0.072 Euro per kWh [2], with the average efficiency of a residential boiler being in proximity to $90 \%$ [3] of the annual fuel utilization efficiency.

In the assessment above, the installation cost of auxiliary heating is not included, since PV-SAC generates heat only periodically. The PV overproduced electricity of up to $2.5 \mathrm{kWh} / \mathrm{d}$ could be used for household needs; therefore, it is calculated as electricity saving.

Increase in the comfort level is achieved by using cooling ceilings. The lifetime of these elements exceeds 20 years. Therefore, the relevant costs could be added to the investments in conventional air conditioning.

Maintenance costs are 1695 Euro in 20 years of PV-SAC operation. The expected gain of electricity overproduction is 4326 Euro in the same time period.

For comparison, the initial investment in CAC is 1200 Euro, and in cooling ceiling it is 2560 Euro including installation. The total investment in CAC (maintenance included) is 19400 Euro in 20 years. Therefore, the profit of 3767 Euro using the PV-SAC technology could be obtained by its substitution for the conventional air conditioning and heating technology $(\mathrm{CAC} \& \mathrm{H})$. The ARR is here:

$$
A R R_{20}=\frac{21472}{17705}=121.3 \%
$$

Figure 2 shows that investment and maintenance costs of conventional technology will exceed the costs of PV-SAC technology in 15 years. The jumps of the curves show periodical replacement of system parts. Thence, the estimated payback time seen in Fig. 2 is 15 years. 


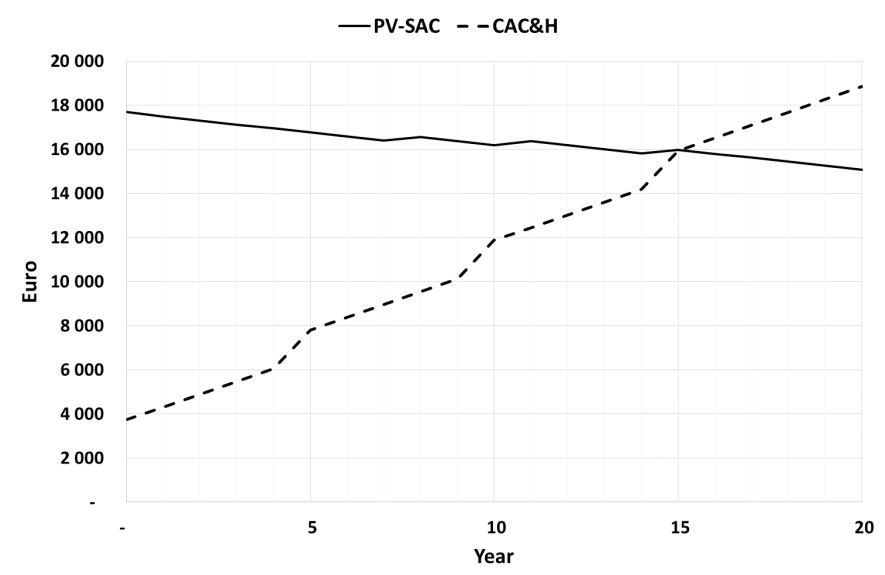

Fig. 2. Initial investment and maintenance costs of PV-SAC and CAC\&H technologies.

The costs of electricity, heat, and equipment replacement are exposed to inflation. Hence, the inflation would increase the revenue of PV-SAC in the future. Possibility of alternative investments decreases the value of future revenue, in which case bank deposit interests could be of help. The deposit interest rate is from $1 \%$ up to $5 \%$, and the annual inflation is usually up to $4 \%$. Respectively, the discount rate could be from $-3 \%$ to $+5 \%$ in a long-term projected future.

Table 1

Net Present Value (NPV) Determination during the PV-SAC System Lifetime

\begin{tabular}{|l|c|c|c|c|c|c|}
\cline { 2 - 7 } \multicolumn{1}{c|}{} & \multicolumn{6}{|c|}{ Discount rate } \\
\cline { 2 - 7 } \multicolumn{1}{c|}{} & $5 \%$ & $3 \%$ & $1 \%$ & $0 \%$ & $-1 \%$ & $-3 \%$ \\
\hline Initial costs & 13945 & 13945 & 13945 & 13945 & 13945 & 13945 \\
\hline NPV, Euro $(€)$ & -2905 & -797 & 1948 & 3633 & 5577 & 10444 \\
\hline
\end{tabular}

The PV-SAC revenue seen in Table 1 shows comparative savings of maintenance costs for PV-SAC and CAC\&H systems. Initial costs include savings obtained by PV-SAC installation instead of CAC\&H. The cost of cooling ceiling installation is not included in the initial cost due to the previously mentioned reason. The results of research indicate that investment in PV-SAC technology is worth doing at the discount rate up to $2.36 \%$. Besides, the payback time is extended by increasing the discount rate.

The PV-SAC provides electricity for its own needs, e.g., for cold generation at the peak cooling consumption. Hence, additional benefit of PV-SAC technology is the utilisation of electricity reserves. The price of long-term electricity reserves is 30 Euro/MWh [4] up to 80 Euro/MWh [5]. The long-term simulation shows that the peak cooling demand is lasting for several weeks a year. Respectively, extra 672 Euro per reference system is saved by utilisation of electricity reserves. 


\section{ENVIRONMENTAL IMPACT}

Energy generation and conversion always include environmental impacts. The use of PV-SAC technology promotes environment-friendly energy generation. Solar energy is renewable, clean, and predictable energy source, so it helps protect environment. Solar energy does not release carbon dioxide $\left(\mathrm{CO}_{2}\right)$, nitrogen oxides, sulfur dioxide, mercury, etc. into the atmosphere as is done using many of conventional heat and electricity sources. Not polluting the air, solar energy does not contribute to global warming, acid rains or smog.

The $\mathrm{CO}_{2}$ content of atmosphere is one of the parameters for revealing the environmental impact of technology use. The potential of $\mathrm{CO}_{2}$ reduction takes into account the $\mathrm{CO}_{2}$ emission factor of the energy used. Therefore, substitution of solar energy for $\mathrm{CO}_{2}$ producing (e.g., fossil) electricity sources reduces its emission into the air, thus reducing global warming.

The world total emission is 35.67 Gton per year [6] in $\mathrm{CO}_{2}$ equivalent. Trends of global emission show that nowadays $\mathrm{CO}_{2}$ emission is $23 \%$ higher than 10 years ago, and $55 \%$ higher than 20 years ago. Electricity and heat production emits $25 \%$ [7] of global greenhouse gas (GHG) emission. Therefore, the reduction of such emissions is one of the main targets of the leading projects of environmental protection.

The estimates of carbon dioxide emissions from the energy sector are based on the methodology worked out by Intergovernmental Panel on Climate Change (IPCC). The European emission factor for the consumed electricity $\left(\mathrm{EF}_{\mathrm{el}}\right)$ is $460 \mathrm{~kg} /$ MWh [8].

The $\mathrm{CO}_{2}$ calculation assumes that for heat generation the natural gas with density $\left(\rho_{\mathrm{NG}}\right)$ of $0.717 \mathrm{~kg} / \mathrm{m}^{3}$ is used. The molecular weight of carbon dioxide $\left(\mathrm{MW}_{\mathrm{CO} 2}\right)$ is $44.0098, \mathrm{~g} / \mathrm{mcl}$, and of carbon $\left(\mathrm{MW}_{\mathrm{C}}\right)-12.011 \mathrm{~g} / \mathrm{mcl}$. The carbon content of the fuel (i.e., natural gas) is assumed to be $74.2 \%$. Lower calorific value of natural gas $\left(\mathrm{LCV}_{\mathrm{NG}}\right)$ is $13.09 \mathrm{kWh} / \mathrm{kg}$. Consequently, the emission factor of stationary combustion heat is $208.86 \mathrm{~kg}$ of $\mathrm{CO}_{2} / \mathrm{MWh}$. This factor decreases to $\mathrm{EF}_{\mathrm{NG}}=207.82 \mathrm{~kg}$ of $\mathrm{CO}_{2} / \mathrm{MWh}$ by taking into account the $\mathrm{CO}_{2}$ oxidation factor.

The PV array generation is $2.344 \mathrm{MWh} / \mathrm{a}$, with an amount of electricity consumed for cold and heat generation and the rest fed into the grid. Overproduction of electricity is $1.04 \mathrm{MWh} / \mathrm{a}$. Conventional air conditioning consumes $1.652 \mathrm{MWh} / \mathrm{a}$ of electricity for the same amount of cold generation. The auxiliary heat source in the CAC\&H system consumes $219 \mathrm{~kg} / \mathrm{a}$ of natural gas for heat generation equivalent to the evaluated technology. Respectively, the reduction in global GHG emission is 1 $835 \mathrm{~kg}$ of $\mathrm{CO}_{2}$ per year.

\section{CONCLUSION}

Solar energy - as a renewable energy source - is available at the same time as room cooling is needed, and in this case a SAC system is a reasonable alternative to the systems using fossil fuel. As previously mentioned, the PV-SAC technology decreases $\mathrm{CO}_{2}$ emission, at the same time increasing the comfort level in living rooms.

It is possible to integrate PV-SAC technology in the common HVAC engineer- 
ing field. Currently, the PV electricity driven solar air conditioning systems are unavailable on the market, so no experience exists as to running such type of systems, despite the commercial availability of all PV-SAC components.

The investments and maintenance costs of conventional SAC technologies are expected to exceed those of PV-SAC technology in 15 years. Investment in the PV$\mathrm{SAC}$ technology is worth doing at a discount rate up to $2.36 \%$.

\title{
REFERENCES
}

1. Snegirjovs, A., Gantenbein, P., Omlin, L., and Shipkovs, P. (2015). Improved model of combined PV solar cooling and free cooling system. $6^{\text {th }}$ International Conference on Solar Air-Conditioning, 162-167. Regensburg, Germany: OTTI.

2. Statistical information centre - Eurostat. Available at www.ec.europa.eu/ eurostat

3. Truong, N. L., and Gustavsson, L. (2014). Cost and primary energy efficiency of smallscale district heating systems. Applied Energy, 130, 419-427.

4. Hummon, M., Denholm, P., and Jorgenson J. (2013). Fundamental Drivers of the Cost and Price of Operating Reserves. Denver, USA: National Renewable Energy Laboratory.

5. Just, S, and Weber, C. (2008). Pricing of reserves: Valuing system reserve capacity against spot prices in electricity markets. Energy Economics, 30, 3198-221.

6. The Emissions Database for Global Atmospheric Research. Available at www.edgar.jrc. ec. europa.eu

7. Ban-Weiss, G. (2013). Electricity production and cooling energy savings from installation of a building-integrated photovoltaic roof on an office building. Energy and Buildings, 56, 210-220.

8. Covenant of Mayors. (2015). The Emission Factors. Technical document. Geneva, Switzerland: The Intergovernmental Panel on Climate Change.

\section{FOTOELEKTRISKĀS SAULES ENERGIJIJS GAISA KONDICIONĒESANĀS DARBİBAS NOVĒRTĒJUMS}

\author{
A.Snegirjovs, P.Šipkovs, K. L,ebedeva, G. Kaškarova, L.Migla, \\ P. Gantenbein, L. Omlin
}

Kopsavilkums

Pieejamā informācija par elektriski darbināmām saules enerǵijas gaisa kondicionēšanas sistēmām (SAC) ir ierobežota. Ievērojams skaits tehnisko datu galvenokārt attiecas uz liela mēroga fotoelektriskajām saules gaisa kondicionēšanas sistēmām. Ticama informācija par šādu sistēmu saražotās enerğijas apjomu ir noskaidrota tikai pēdējo gadu laikā, taču tā bieži vien nav publiski pieejama, kaut arī ir liela saules enerǵijas pētnieku un inženieru interese par šāda veida SAC sistēmām. Šajā pētījumā tiek analizēta PV-SAC tehnologijija, kurā izmantota mazjaudas sistēmas (ar vidējo dzesēšanas jaudu līdz 15 kWp), darbības novērtējums. Šāda sistēma ietver 
PV elektriski darbināmu kompresijas dzesētāju ar aukstuma un siltuma enerǵijas uzkrājējiem un siltumenerǵijas novadīšanu karstā ūdens vajadzībām. Ne-dzesēšanas sezonā ir iespējams izmantot šo sistēmu apgrieztā režīmā. Šajā režīmā apkārtējais gaiss kalpo kā siltuma avots. Turklāt «brīvā dzesēšana» ir paredzēta PV-SAC sistēmas koncepcijā.

22.11.2016. 